\title{
Faktor Penghambat Guru sebagai Fasilitator dalam Pembelajaran Sosiologi di SMAN 2 Batusangkar
}

\author{
Miftahul Jannah ${ }^{1}$, Junaidi Junaidi ${ }^{2}$ \\ ${ }^{1,2}$ Universitas Negeri Padang \\ Email: mitukw@gmail.com, junaidiunp@fis.unp.ac.id
}

\begin{abstract}
Abstrak
Artikel ini menjelaskan hasil penelitian dengan fokus masalah hambatan guru sebagai fasilitator dalam pembelajaran. Penelitian bertujauan untuk mendeskripsikan faktor penghambat guru berfungsi sebagai fasilitator dalam pembelajaran sosiologi di SMAN 2 Batusangkar. Hasil penelitian ini berguna bagi sekolah dan guru untuk meningkatkan fungsi guru fasilitator. Penelitian ini menggunakan pendekatan kualitatif dengan tipe penelitian studi kasus. Teknik pemilihan informan yang dipilih adalah purpose sampling. Teknik pengumpulan data dilakukan dengan cara observsi, wawancara, dan studi dokumentasi. Data dianalisis menggunakan teknik dari Miles dan Huberman terdiri atas reduksi data, penyajian data, dan penarikan kesimpulan. Hasil penelitian menunjukan faktor yang menghambat guru sebagai fasilitator disebabkan oleh beberapa faktor, yaitu faktor dari sekolah, faktor guru, dan siswa. Faktor dari sekolah yaitu kurang maksimalnya fasilitas yang mendukung pengalaman belajar siswa, terutama dalam menyediakan sumber belajar atau buku. Faktor dari guru adalah : 1) guru kurang memiliki pengetahuan untuk memvariasikan media pembelajaran, 2) guru belum sepenuhnya melaksanakan pembelajaran sesuai dengan RPP, 3) guru fokus terhadap pemberian materi belajar, 4) guru terlalu mendominasi dalam belajar. Faktor dari siswa karena siswa tidak memiliki motivasi, siswa tidak fokus, serta tidak memiliki minat belajar. Teori yang sesuai untuk menganalisis masalah pada penelitian diatas adalah Teori Peran dari Robert Linton, Biddle dan Thomas, serta beberapa pendapat ahli lain yang masih mengkaji tentang Teori Peran
\end{abstract}

Kata kunci: peran guru, fasilitator, faktor penghambat

Abstract
This study focuses more on what factors are hampering teachers as facilitators in learning sociology at SMAN 2 Batusangkar. This study aims to determine the factors that hinder teachers as facilitators at SMAN 2 Batusangkar. Research is useful as a reference for teachers and schools to find solutions related to the obstacles of teachers as facilitators. This study uses a qualitative approach to the type of case study research. The informant selection technique chosen was purpose sampling. Data collection techniques carried out by way of observation, interviews, and study documentation. Data were analyzed using techniques from Miles and Huberman consisting of data reduction, data presentation, and drawing conclusions. The results showed that the factors that prevented the teacher as a facilitator were caused by several factors, namely factors from the school, teacher factors, and students. The factor of the school is the lack of facilities that support student learning experiences, especially in providing learning resources or books. Factors from teachers such as: 1) teachers lack knowledge to apply the media used, 2) teachers have not fully implemented learning in accordance with the RPP, 3) teachers focus on providing learning material 4) teachers are too dominant in learning. Factors of students because students do not have motivation, students are not focused, and do not have interest in learning. Appropriate theories for analyzing problems in the research above are Role Theory from Robert Linton, Biddle and Thomas, as well as several other expert opinions that are still examining Role Theory.

Keywords: the role of the teacher, facilitator, inhibiting factor

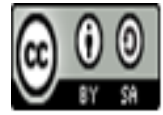

Received: January 16, 2020 $\quad$ Revised: January 28, $2020 \quad$ Accepted: January 29, 2020 


\section{Pendahuluan}

Sosiologi adalah satu di antara mata pelajaran di lembaga pendidikan Sekolah Menengah Atas (SMA) memiliki peran penting yang berusaha mengembangkan pemahaman peserta didik terhadap konsep dan fenomena sosial yang terjadi dalam kehidupan sehari hari. Dengan adanya pemahaman maka peserta didik diharapkan dapat memiliki kemampuan untuk menghadapi dan menyelesaikan berbagai masalah sosial yang ditemuinya dalam kehidupan sehari-hari. (Hadi and Junaidi 2018)

Prioritas pembangunan bidang pendidikan di Indonesia saat ini adalah pe- ningkatan mutu pendidikan. (Sylvia 2013). Tantangan guru abad 21 adalah harus memiliki kemampuan mempersiapkan peserta didik yang unggul dan memiliki kecakapan yang dibutuhkan di abad 21, yaitu adanya ketrampilan yang harus dimiliki oleh peserta didik yaitu ketrampilan 4C (Critical thinking, Communication, Collaborative dan Creative).(Dendy Marta Putra 2019) Oleh karena itu tugas guru adalah mendesain, melaksanakan pembelajaran sesuai dengan rancangannya, serta mampu mengevaluasinya. Selain itu guru juga perlu memikirkan cara mentransformasikan kecakapan tersebut ke dalam diri para peserta didiknya melalui perencanaan, pelaksanaan, dan evaluasi pembelajarannya secara terarah, efektif dan efisien. Dengan dibekali kecakapan ini sebagai tambahan kecakapan akademik peserta didik akan terbantu memecahkan permasalahan individual dan sosial yang dihadapi dalam kehidupan di lingkungannya. (Sylvia et al. 2019)

Guru yaitu orang yang memiliki peran penting dalam dunia kependidikan yang bertanggung jawab atas perkembangan peserta didik secara utuh baik dalam hal spiritual maupun dari segi fisik. Muh Zein, (2016: 279-280) menjelaskan bahwa peranan guru meliputi peranan-peranan yang lebih spesifik yakni, guru sebagai model, guru sebagai perencana, guru sebagai peramal, guru sebagai pemimpin, guru sebagai penunjuk jalan atau pembimbing ke arah pusat-pusat belajar (Zein 2016). Sadirman (2011: 144-146), menjelaskan bahwa guru memiliki beberapa peranan dalam pembelajaran, peranannya antara lain guru sebagai informator, organisator, motivator, pengarah atau director, inisiator, transmitter, fasilitator, mediator, dan evaluator (A.M 2011). Peran guru sebagai fasilitator dapat berupa menyedian fasilitas belajar agar dapat membantu dalam pencapaian tujuan pembelajaran (Mulyasa 2015). Menurut Hamalik, Oemar (2008: 45), Peran pertama meliputi: guru sebagai model, guru sebagai perencana, guru sebagai peramal, guru sebagai pemimpin dan guru sebagai penujuk jalan atau pembimbing ke arah pusat-pusat belajar (Hamalik 2008).

Menurut Hasibuan, Rukaiah Proklamasi (2017: 400), peran guru dalam pembelajaran adalah guru harus kreatif, profesional dan menyenangkan, dengan memposisisikan diri sebagai: orang tua (yang penuh kasih sayang kepada peserta didik), teman (teman mengadu dan mengutarakan perasaan bagi peserta didik), fasilitator (siap memberikan kemudahan dan melayani peserta didik sesuai minat, kemampuan dan bakatnya) (Hasibuan 2017). Menurut Wina Sanjaya (2014: 21-23), guru akan menjadi optimal sebagai fasilitator jika guru mampu menyediakan media dan sumber belajar dan mampu memanfaatkan bermacam-macam media pembelajaran (Yonanda 2011). Menurut Sindhunata (2001: 3-5), selaku fasilitator guru harus bersikap mendengarkan dan tidak mendominasi, bersikap sabar, menghargai dan rendah hati, mau belajar, bersikap sederajat, agar bisa diterima oleh peseta didik, bersikap akrab dan melebur, tidak berusaha menceramahi, berwibawa, tidak memihak dan mengkritik, bersikap terbuka, danbersikap positif. Tugas guru menurut Alawiyah, Faridah (2013: 71) terbatas menyusun rencana pembelajaran, melaksanakan pembelajaran, serta melakukan penilaian pembelajaran (Alawiyah 2013).

Menurut Ningsih (2017, 2-5), pelaksanaan peran oleh guru dala pembelajaran seharusnya meliputi: (1) Menyediakan pengalaman belajar terdiri atas media pembelajaran sebagai salah satu fasilitas dari guru untuk memudahkan proses belajar, sumber belajar karena sumber belajar dimanfaatkan selama belajar dalam mengumpulkan informasi sesuai dengan tujuan belajar,

Jurnal Sikola: Jurnal Kajian Pendidikan dan Pembelajaran Vol. 1, No. 3, Th. 2020 
bahan ajar dimaksudkan agar guru dan siswa memiliki pedoman yang jelas dalam proses belajar, (2) Mengutamakan kegiatan meransang tingkat keingintahuan siswa terbagi dalam kegiatan pendahuluan agar guru memperhatikan keadaan sekitar kelas sebelum belajar, kegiatan inti agar guru melaksanakan proses pembelajaran mengacu pada rancangan pembelajaran yang sudah dibuat atau di rencanakan, dan kegiatan penutup supaya guru mengakhiri dengan melakukan kuis atau tanya jawab kepada siswa, 3. Memonitor dan mengevaluasi siswa diharapkan guru mampu mengamati siswa dan memberikan penilaian terkait hasil belajar siswa sebagai bentuk ukuran sejauh apa pemahaman siswa dalam belajar (Ningsih 2017).

Peran guru selaku fasilitator seperti yang dijelaskan di atas tidak berjalan pada sekolah SMAN 2 Batusangkar. Pelaksanaan peran guru sebagai fasilitator tidak sesuai dengan tuntutan Kurikulum 2013 yang mengutamakan siswa menjadi kritis, terbuka dan responsif. Peran fasilitator yang tidak berjalan baik juga tampak dari beberapa indikator yang tidak dipenuhi oleh guru sosiologi di SMAN 2 Batusangkar ini. Indikator yang tidak berjalan adalah guru sebagai penyedia pengalaman belajar. Guru tidak mampu menjalankan peran sebagai media, sumber, dan bahan ajar karena fasilitas yang kurang dan siswa yang kurang berminat dalam belajar. Indikator guru sebagai fasilitator selanjutnya yang tidak berjalan adalah guru sebagai peransang pengetahuan siswa, karena mulai dari kegiatan pembuka, kegiatan inti, dan kegiatan penutup guru kurang bagus dalam memanfaatkan waktu sehingga belajar tidak sesuai dengan rancangan pada RPP. Indikator guru sebagai evaluator sudah berjalan baik dibuktikan dengan guru melakukan penilaian saat proses belajar berlangsung dan saat guru memberikan kuis atau tanya jawab saat jam pembelajaran usai.

Penelitian dengan topik yang sama sudah dilakukan oleh Nefi Maidia Ningsih, Fenti Putri Yonanda, dan Ria Agustina tentang pelaksanaan guru sebagai fasilitator dengan hasil guru belum berhasil sebagai fasilitator karena memiliki hambatan (Agustina 2017). Persamaan penelitian yang peneliti lakukan dengan ketiga penelitian di atas adalah sama-sama membahas tentang peran guru selaku fasilitator. Perbedaannya adalah ketiga penelitian relevan di atas memfokuskan untuk melihat pelaksanaan peran guru sebagai fasilitator, sedangkan penelitian yang peneliti lakukan bertujuan melihat faktor penghambat guru dalam melaksanakan perannya sebagai fasilitator .

Berdasarkan gambaran di atas dilihat bahwa fakta guru sosiologi SMAN 2 Batusangkar masih sama dengan yang terjadi di penelitian- penelitian terdahulu, yaitu belum berhasil melaksanakan perannya sebagai fasilitator karena beberapa hambatan. Selain itu, guru selaku fasilitator yang di tuntut oleh Kurikulum 2013 agar siswa mampu berfikir kritis dan dapat cepat tanggap memberikan respon dalam belajar tidak terwujud. Oleh sebab itu, peneliti merasa perlu melakukan penelitian dengan judul Faktor Penghambat Guru sebagai Fasilitator dalam Pembelajaran Sosiologi di SMAN 2 Batusangkar.

Teori yang digunakan pada penelitian ini adalah Teori Peran. Menurut Linton (1936, dalam Hutami, 2011), menyatakan bahwa teori peran menggambarkan interaksi sosial aktor yang bermain sesuai dengan apa yang telah di tetapkan oleh budaya. Menurut teori ini Linton menyatakan bahwa seseorang memiliki peran tertentu contohnya, dokter, mahasiswa, orangtua, wanita dan lain sebagainya dengan harapan orang tersebut berperilaku sesuai dengan peran tersebut (Hutami 2011). Ahmad dan Taylor (2009), menyatakan teori peran adalah ketika perilaku yang di harapkan oleh individu tidak konsisten, maka mereka dapat mengalami stress, merasa tidak puas, depresi. Jika harapan mereka tidak mengandung konflik, maka kinerja mereka akan kurang efektif. Artinya, konflik juga bisa memberikan efek negatif terhadap cara berfikir seseorang.

Suhardono, Edi (1994: 3), menjelaskan bahwa peran diartikan pada karakter yang di sandang untuk dimainkan seseorang aktor dalam sebuah panggung drama. Secara sosial peran diartikan sebagai fungsi yang dibawakan oleh seseorang ketka menduduki suatu posisi dalam struktur sosial (Suhardono 1994). Menurut Sarwono (1995: 209), menyatakan posisi aktor dalam teater disamakan dengan posisi orang di masyarakat yang tidak bisa berdiri sendiri, melainkan

Jurnal Sikola: Jurnal Kajian Pendidikan dan Pembelajaran Vol. 1, No. 3, Th. 2020 
selalu berada dalam hubungan yang berkaitan dengan aktor tersebut (Sarwono 2015). Menurut Biddle dan Thomas (dalam Sarwono, Sartlito Wirawan, 2015: 215), golongan teori peran terbagi atas: 1 . Orang yang melakukan interaksi social, 2. Adaya perilaku yang timbul dalam interaksi social terdiri atas: harapan, norma, wujud. 3. Adanya kedudukan orang yang memiliki peran, 4. Memiliki kaitan antara orang dan perannya: differensiasi, konsensus, konflik peran, keseragaman, spesialisasi, konsistensi, ransangan atau hambatan, ganjaran atau hukuman, serta adanya hubungan.

Berdasarkan penjelasan beberapa pendapat ahli, dapat di ambil kesimpulan bahwa Teori Peran adalah teori yang menjelaskan seseorang memiliki peran sesuai dengan kedudukan dan struktur yang mengikat sehingga seseorang harus memainkan sikap atau karakter yang sesuai dengan peran yang di jalankannya. Jika seseorang yang mendapatkan sebuah peran tidak selalu sesuai dengan tujuan yang ingin di capainya. Kadangkala seseorang tidak menjalankan peran sesuai dengan yang seharusnya sehingga menimbulkan konflik peran. Konflik peran akan menimbulkan efek negatif kepada aktor, tetapi juga berfungsi untuk meningkatkan aktor untuk bertindak sesuai dengan yang tuntutan perannya (Agustina 2009).

\section{Metode Penelitian}

Metode yang digunakan dalam penelitian adalah pendekatan kualitatif (Sugiyono 2009). Tipe penelitian yang digunakan yaitu studi kasus (Nazir 2005). Teknik yang dilakukan adalah purpose sampling dengan jumlah informan sebanyak 12 orang. Teknik pengumpulan data yang dilakukan adalah observasi, wawancara, studi dokumentasi dan menguji data dengan melakukan Triangulasi Sumber dan Triangulasi Teknik. Data dianalisis dengan teknik dari Miles dan Huberman yaitu reduksi data, penyajian data, dan penarikan kesimpulan.

\section{Hasil dan Pembahasan}

\section{Pelaksanaan Peran Guru sebagai Fasilitator}

Penyediaan pengalaman belajar yang terdiri dari: a) Media belajar, dalam hal ini guru meyediakan media berupa gambar saja dan sesekali menganjurkan siswa memanfaatkan lingkungan sekitar sebagai media belajar, b). sumber belajar yang di manfaatkan guru untuk mengajar masih sangat sedikit, apalagi siswa yang memakai buku juga disebabkan karena sebagian guru sosiologi yang memakasa siswa harus punya buku, c) bahan ajar yang dimanfaatkan masih sejalan dan satu fungsi dengan sumber belajar. Bahan ajar yang dipakai oleh salah satu guru sosiologi berbentuk modul yang dibuat oleh guru itu sendiri. Walaupun sumber belajar dan bahan ajar itu berkaitan, tetap saja itu tidak sama atau berbeda (Junaidi, Sumber Belajar dalam Membelajarkan Sosiologi, 2018)

Tahap ini merupakan bagian guru memperhatikan kegiatan pendahuluan, kegiatan inti dan kegiatan penutup. Pada kegiatan pendahuluan guru jarang memberikan stimulus kepada siswa karena guru telat masuk kelas. Guru lebih fokus untuk menyampaikan materi ajar. Pada tahap kegiatan inti, guru lebih sering menjelaskan dengan metode ceramah sehingga terlalu mendominasi dalam belajar. Pada kegiatan penutup seharusnya guru melakukan tanya jawab dan menyiapkan pembelajaran untuk pertemuan selanjutnya (Maswira, 2013). Akan tetapi, guru jarang sekali melakukan kegiatan tanya jawab karena waktu sudah habis

Mengevaluasi siswa sudah dilakukan oleh guru saat proses belajar berlangsung dan saat kuis setelah pembelajaran usai, hanya saja guru belum konsisten melakukan penilaian tersebut atau hanya sesekali saja. Seharusnya, guru memanfaatkan tahap ini untuk mengasah siswa mampu berfikir kritis menjawab pertanyaan dari guru berkaitan dengan materi yang sudah di jelaskan, karena pembelajaran sosiologi menuntut peserta didik untuk mampu berfikir kritis (Indrahadi \& Junaidi, 2017).

Kesimpulan mengenai pelaksanaan guru sebagai fasilitator di SMAN 2 Batusangkar ini menjelaskan bahwa guru belum melaksanakan kegiatan pembelajaran sesuai dengan RPP, guru

Jurnal Sikola: Jurnal Kajian Pendidikan dan Pembelajaran Vol. 1, No. 3, Th. 2020 
hanya menggunakan media visual saja, dan guru terlalu mendominasi belajar dengan cara bercermah.

Tabel 1. Pelaksanaan guru sebagai fasilitator di SMAN 2

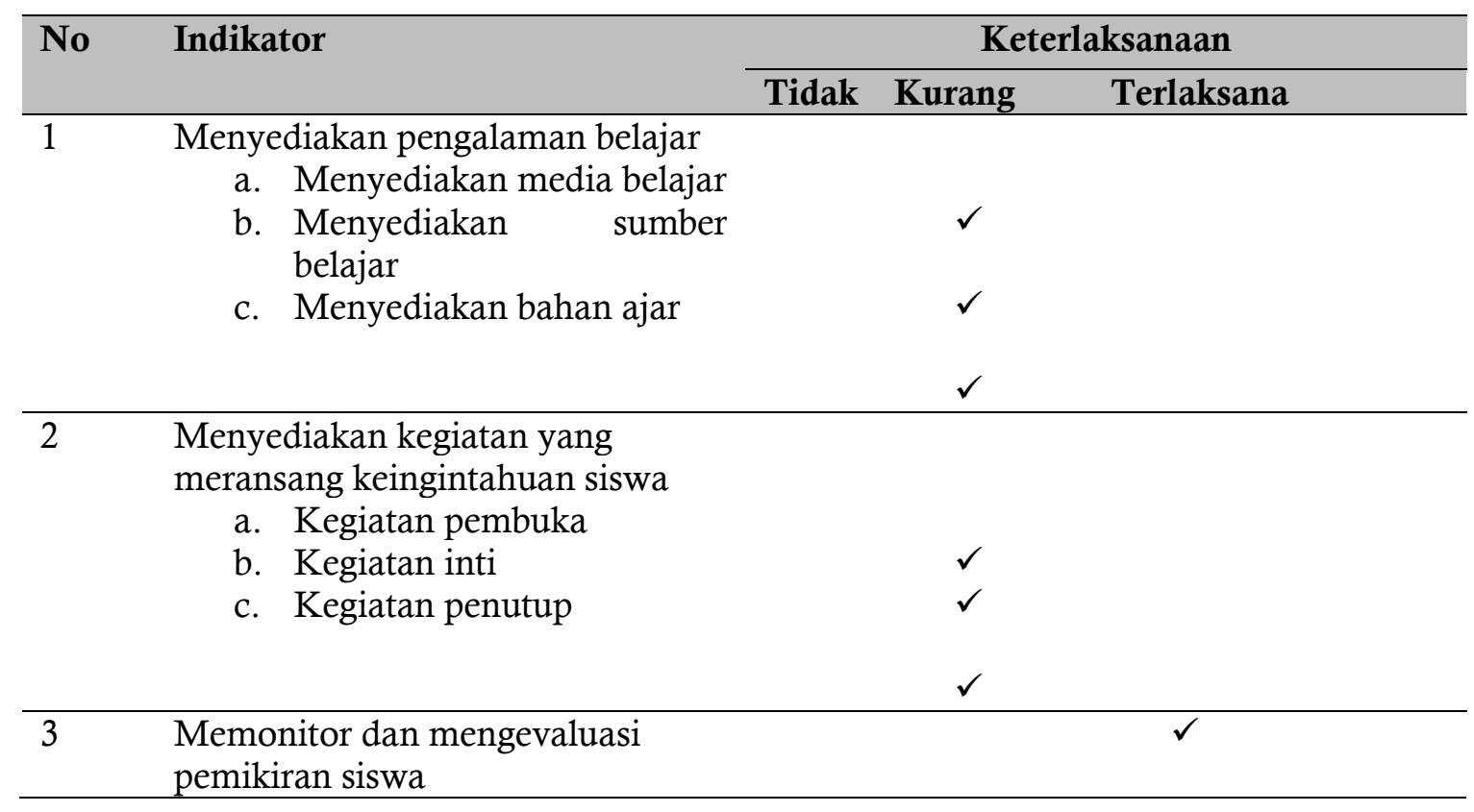

\footnotetext{
Faktor Penghambat Guru sebagai Fasilitator dalam Pembelajaran Sosiologi di SMAN 2 Batusangkar

Berdasarkan hasil penelitian terkait faktor yang menghambat guru sebagai fasilitator adalah sebagai berikut:
}

\section{Penyediaan pengalaman belajar}

\section{Media belajar}

Faktor yang menghambat guru menyedikan media belajar itu dipengaruhi oleh faktor guru dan faktor siswa. Faktor penghambat yang bersumber dari guru berupa: a) guru hanya menyediakan media belajar visual dan tidak bervariasi, b) guru tidak siap terhadap perubahan IPTEK sehingga guru merasa repot menggunakan proyektor dan laptop dalam menerapkan media audio visual, c) pengetahuan guru kurang dalam membedakan antara media dan model pembelajaran. Sedangkan faktor dari siswa yang menyebabkan terhambatnya peran guru sebagai fasilitator terkait media belajar karena, siswa lengah dengan gambar yang di berikan. Akhirnya, media gambar menjadi bahan bercandaan hingga kelas menjadi rusuh dan justru tidak menjadi salah satu cara yang baik untuk belajar.

Berdasarkan teori peran menurut pendapat Biddle dan Tomas, teori peran merupakan orang yang di sebut aktor memiliki sebuah peran yang di dalamnya terdapat interaksi aktor dan target. Ketika orang yang memiliki peran tidak sesuai dengan perannya, maka akan muncul konflik peran. Selain itu, Bidlle dan Thomas juga membahas bahwa dalam menjalankan perannya, aktor akan memiliki halangan atau hambatan. Ini berkaitan bahwa dalam menyediakan media belajar, guru tidak berhasil berperan sebagai fasilitator. Sesuai dengan masalah di atas, hambatan yang dialami karena guru hanya menggunakan media visual saja, guru tidak memahami perbedaan media dan model, serta guru tidak siap akan perubahan IPTEK. 


\section{Sumber belajar}

Faktor utama yang menghambat guru sebagai fasilitator dalam menyediakan sumber belajar adalah karena faktor sekolah. Sekolah kurang maksimal dalam menyediakan fasilitas yang mendukung pengalaman belajar siswa khususnya sumber belajar sosiologi. Sumber belajar yang dimaksud berupa buku teks siswa yang tersedia di perpustakaan sekolah. Karena keterbatasan tersebut, guru membuat modul sebagai salah yang bisa di jadikan sumber belajar siswa.

Berdasarkan teori peran yang mengambil pendapat dari Biddle dan Tomas bahwa dalam teori peran terdapat konsep perilaku yang timbul akibat interaksi orang yang memiliki peran. Perilaku terbagi atas harapan kepada pemilik peran, norma yang diikuti aktor yang berperan, serta wujud dari peran yang di jalankan. Konsep dalam teori ini sesuai dengan masalah di atas bahwa harapannya guru tetap bisa menjalankan peran fasilitatornya dengan segala kekurangan yang ada. Norma yang mengikat adalah guru sebagai fasilitator harus berhasil melaksanakan peranya sebagai fasilitator terutama sebagai penyedia sumber belajar. Selanjutnya, wujud perannya adalah guru sebagai penyedia sumber belajar menyediakan modul sebagai salah sumber belajar.

\section{Bahan ajar}

Hambatan guru sebagai fasilitator dalam menyediakan bahan ajar adalah faktor guru itu sendiri yang masih belum menyediakan bahan ajar dengan baik. Salah satu guru menggunakan bahan ajar modul sebagai sumber sekaligus bahan ajar. Sebagian lagi guru hanya berpatokan dengan RPP, namun tidak melaksanakan kegiatan yang sudah tersusun seperti RPP tersebut. Faktor yang menjadi hambatan selanjutnya adalah siswa. Siswa tidak memiliki minat belajar, dan tidak memiliki motivasi dalam belajar sehingga bahan ajar yang sudah di sediakan tidak berfungsi sebagaimana mestinya. Berdasarkan teori peran menurut Biddle dan Tomas menjelaskan bahwa dalam teori peran terdapat konflik peran ketika aktor yang sedang berperan tidak menjalankan perannya. Ini berkaitan bahwa dalam menyediakan bahan ajar, guru tidak berhasil berperan sebagai fasilitator, buktinya guru tidak menyediakan bahan ajar dengan baik. Biddle dan Thomas juga menyatakan bahwa setiap peran mengalami hambatan dalam menjalankan peran. Sesuai dengan masalah di atas, hambatan yang alami adalah karena guru itu sendiri dan siswa yang tidak minat serta siswa yang tidak punya motivasi dalam belajar.

\section{Kegiatan dalam meransang keingintahuan siswa}

Hambatan pada tahap ini dilihat dari yang dilakukan guru mulai dari kegiatan pembuka, kegiatan inti, dan kegiatan penutup. Kegiatan pendahuluan seperti memberikan stimulus kepada siswa sering tidak terlaksanakan, kegiatan penutup seperti menguji pemahaman siswa tentang materi yang sudah dipelajari juga sering terlewatkan. Penyebabya karena guru fokus untuk menyampaikan materi saja dan tidak memperhitungkan waktu dengan baik. Faktor yang menjadi penghambat adalah faktor dari guru itu sendiri karena tidak melaksanakan kegiatan pembelajaran sesuai dengan RPP yang sudah dibuat. Sedangkan pada dasarnya guru harus memahami RPP karena berpengaruh tercapainya hasil belajar yang baik serta guru harus menjalankan RPP secara terpogram dan terstruktur (Marwa, 2019). Hal ini sesuai dengan kajian teori peran bahwa aktor dalam menjalankan peran akan memiliki pengaruh atau hambatan. Masalah ini berkaitan karena guru tidak mejalankan perannya sebagai fasilitator karena memiliki hambatan sehingga guru tidak mampu menjalankan perannya dengan baik.

\section{Guru memonitor dan mengevaluasi siswa}

Pada bagian ini faktor yang menjadi hambatan guru sebagai fasilitator adalah karena guru belum konsisten terhadap proses penilaian yang dilakukan. Pernyataan di atas bisa di kaji dengan teori peran yang menjelaskan bahwa aktor di dalam peran memiliki target untuk menjalankan perannya. Artinya, guru merupakan aktor dan memiliki peran untuk mengevaluasi, dan siswa sebagai target aktor untuk menjalankan perannya selaku fasilitator untuk dievaluasi.

Jurnal Sikola: Jurnal Kajian Pendidikan dan Pembelajaran Vol. 1, No. 3, Th. 2020 


\section{Kesimpulan}

Berdasarkan penelitian yang telah dilakukan, mendapatkan hasil bahwa faktor yang menghambat guru belum bisa melaksanakan perannya selaku fasilitator, dibebakan oleh beberapa faktor yaitu faktor sekolah, faktor guru, dan faktor dari siswa. Faktor dari sekolah karena fasilitas yang belum maksimal untuk mendukung pengalaman belajar siswa khususnya menyediakan sumber belajar. Faktor dari guru terdiri atas: guru yang tidak menjalankan kegiatan pembelajarn sesuai dengan RPP, pengetahuan guru yang kurang dalam memahami media dan model yang dgunakan dalam belajar, guru yang masih belum siap terhadap perkembangan IPTEK, serta guru masih mendominasi dalam belajar. Sedangkan faktor dari siswa berupa: siswa yang tidak memiliki minat belajar dan tidak memiliki motivasi belajar. Oleh sebab itu, peran guru seaku fasilitator tidak berjalan baik karena tidak sesuai dengan indikator yang seharusnya.

\section{Daftar Pustaka}

A.M, Sadirman. 2011. Interaksi Dan Motivasi Belajar Mengajar. Jakarta: Rajawali Press.

Agustina, Lidya. 2009. Pengaruh Konflik Peran, Ketidakjelasan Peran Terhadap Kepuasan Kerja dan Kinerja Auditor. Akuntansi Vol. 1, No: 43.

Agustina, Ria. 2017. Peran Guru Sebagai Fasilitator Dalam Proses Pembelajaran Pendidikan Agama Islam Di SMP Negeri 1 Wonosobo Kabupaten Tanggamus. UIN Raden Intan Lampung.

Alawiyah, F. 2013. Peran Guru dalam Kurikulum. Aspirasi Vol.4:71.

Dendy Marta Putra, Nurlizawati Nurlizawati. 2019. Lesson Study dalam Meningkatkan Ketrampilan 4C (Critical Thingking, Collaborative, Communicative Dan Creative) Pada Pembelajaran Sosiologi Yang Terintegrasi ABS-SBK Di SMAN 1 Pasaman. Jurnal Sikola: Jurnal Kajian Pendidikan Dan Pembelajaran I(2): 139-46.

Hadi, Deri Indra and Junaidi Junaidi. 2018. Upaya Meningkatkan Kemampuan Berpikir Kritis Melalui Penerapan Model Pembelajaran Berbasis Masalah Pada Pembelajaran Sosiologi Kelas Xi IPS 2 SMA Negeri 1 Pariaman. Socius 4(1): 22.

Hamalik, O. 2008. Perencanaan Pembelajaran Berdasarkan Pendekatan Siswa. Jakarta: Bumi Aksara.

Hasibuan, R. P. 2017. Peran Guru dalam Pendidikan. 400. Retrieved (http://semnasfis.unimed.acid/wp-content/uploads/2017/06/PERAN-GURU-DALAMPENDIDIKAN.pdf).

Hutami, Gartiria. 2011. Pengaruh Konlik Peran dan Ambiguitas Peran Terhadap Komitmen Independensi Auditor Internal Pemerintah Daerah. 5. Retrieved (http://eprints.undip.ac.id/30903/).

Mulyasa. 2015. Guru Dan Implementasi Kurikulum 2013. Bandung: Remaja Rosdakarya.

Nazir, Moh. 2005. Metode Penelitian. 6th ed. Jakarta: Ghalia Indonesia.

Ningsih, Nefi Maida. 2017. Pelaksanaan Fungsi Guru Sebagai Fasilitator dalam Pembelajaran Sosiologi Di SMAN 2 Lubuk Basung. Skripsi 2-5. Retrieved (http://repo.stkip-pgrisumbar.ac.id/id/eprint/1878).

Sarwono, Sarlito Wirawan. 2015. Teori-Teori Psikologi Sosial. Jakarta: Rajawali Pers.

Sugiyono. 2009. Metode Penelitian Kuantitatif, Kualitatif, dan R\&D. Bandung: Alfabeta.

Suhardono, Edi. 1994. Teori Peran (Konsep, Derivasi dan Implikasinya). Jakarta: PT. Gramedia Pustaka Utama.

Jurnal Sikola: Jurnal Kajian Pendidikan dan Pembelajaran Vol. 1, No. 3, Th. 2020 
Sylvia, Ike. 2013. Pemetaan Kompetensi Siswa SMA Pada Mata Pelajaran Sosiologi Di Kota Pariaman Dan Kabupaten Padang Pariaman Provinsi Sumatera Barat. Diakronika, Vol. XII No.1 Th. 2012 XIII(1): 35-43.

Sylvia, Ike, Syafri Anwar, Khairani Khairani, Universitas Negeri Padang, Penilaian Autentik, and Pembelajaran Sosiologi. 2019. Pengembangan Instrumen Penilaian Autentik Berbasis Pendekatan Authentic Inquiry Learning Pada Mata Pelajaran Sosiologi Di Sekolah Menengah Atas. 6(2): 103-20.

Yonanda, Fenty P. 2011. Pelaksanaan Fungsi Guru Sebagai Fasilitator Dalam Pebelajaran Sosiologi. Universitas Negeri Padang.

Zein, Muh. 2016. Peran Guru Dalam Pengembangan Pembelajaran. Jurnal Inspiratif Pendidikan, $5,(2), 279-80$. 